\title{
Anemia and iron deficiency in infants aged 6-12 months in the city of Necochea: Prevalence and determinants
}

\author{
Nicolás Molina Favero, M.D. ${ }^{a}$ and Vilma Rens, B.S. in Biochemistry ${ }^{b}$
}

\begin{abstract}
Introduction. Anemia in the first years of life leads to severe psychomotor, social, and financial effects. The objective of this study was to determine its prevalence, causes, and risk and preventive factors among infants in the city of Necochea.

Population and methods. Observational, descriptive, and cross-sectional study. Healthy infants aged 6-12 months who attended a spontaneous health checkup in a public and/ or private facility in the district of Necochea during 2017 were assessed. An informed consent was obtained; a social and nutrition survey was administered; dietary and medicinal iron intake was assessed; and a physical examination and lab tests were done.

Results. A total of 239 participants wereincluded; $50.6 \%$ had anemia and $47.3 \%$, iron deficiency. Mean and median hemoglobin levels were both $10.9 \mathrm{~g} / \mathrm{dL}$, (reference mean: $12.5 \mathrm{mg} / \mathrm{dL}$ ). Among anemia patients, $54.4 \%$ had iron deficiency; iron intake was inadequate in $61.7 \%$; and $44.3 \%$ had not received iron supplementation the previous day. Among these, $24.5 \%$ had not received a medical indication for it, and $9.1 \%$ did not find iron supplementation available at their primary health care center or hospital. An adequate iron intake was a protective factor against iron deficiency (relative risk [RR]: 0.78 [95\% confidence interval $\{\mathrm{CI}\}: 0.6-0.9]$ ]), but not against the development of anemia (RR: 1.08; [95\% CI: 0.8-1.3]).

Conclusions. In the city of Necochea, anemia and iron deficiency are highly prevalent conditions; dietary iron intake is insufficient and supplementation is under-prescribed.

Key words: anemia, iron deficiency anemia.
\end{abstract}

http: / / dx.doi.org/10.5546/ aap.2020.eng.187

To cite: Molina Favero N, Rens V. Anemia and iron deficiency in infants aged 6-12 months in the city of Necochea: Prevalence and determinants. Arch Argent Pediatr 2020;118(3):187-192.
Nicolás Molina Favero, M.D.:

nmolinafavero@gmail. com

\section{Funding:}

None

Conflict of interest:

None.

Received: 2-15-2019

Accepted: 12-23-2019

\section{INTRODUCTION}

Anemia is defined as a reduced hemoglobin ( $\mathrm{Hb})$ level below 2 standard deviations (SDs) for sex and age, and its most common cause is iron deficiency (ID). ${ }^{1-3}$ Anemia is considered a marker of social inequality and a severe public health problem. If not detected early, it causes severe neurological disorders, including a lower intelligence quotient, poor reading and writing skills and math performance, a higher school repetition index, and a deficient socio-affective development; ${ }^{2,5-9}$ it also leads to impaired development, immune answer, and physical and work performance, among other consequences. ${ }^{1-3}$

ID is caused by a persistently negative balance, ${ }^{3,5}$ which mainly depends on the deposits acquired towards the end of gestation and iron bioavailability in the type of milk consumed. Then, it will depend on intestinal absorption from diet, nutritional status, still immature regulatory factors, and their relation to absorption facilitators, such as vitamin $C$, fructose, citric acid, and lactic acid, or inhibitors, like phosphates, phytates (bread), calcium (dairy), fibers, polyphenols, and tannins (coffee, tea, chocolate). . $-3,6,10,11^{-1}$ The greatest iron bioavailability is found in meat.

The following are risk factors for ID and anemia: early umbilical cord clamping, twin pregnancy, preterm birth, maternal anemia, inadequate or untimely complementary feeding, non-fortified milk intake, parasitic disease, and intestinal mucosa irritation; and also social conditions, such as low income, low educational 
environment, malnutrition, undernutrition, and unmet basic needs (UBNs).,12-15 According to the National Survey on Nutrition and Health (Encuesta Nacional de Nutrición y Salud, ENNyS), ${ }^{12-14}$ anemia prevalence showed a great inter-regional variation, from $16.5 \%$ among children younger than 5 years to $34.1 \%$ among those aged 6-24 months and $47.6 \%$ among 6-12-month-old infants. Among these children with anemia, $54 \%$ had ID.

At 1 year old, in Argentina, $72 \%$ of children are still breastfed ${ }^{16}$ and 3 out of 4 of those who are not breastfed are exclusively fed with non-fortified milk; of these, $50 \%$ do not meet the minimum iron requirements. As of 6 months old, many infants receive food with a poor iron and calorie intake, ${ }^{17}$ only $40 \%$ refer meat intake the previous day, and more than half eat low quality meats.

The Argentine Society of Pediatrics (Sociedad Argentina de Pediatrí, SAP), the World Health Organization (WHO), and the American Academy of Pediatrics (AAP) recommend iron administration as of 4 months old to exclusively and partially breastfed infants until highly bioavailable iron sources are introduced. ${ }^{1-3,6,18}$ The REMEDIAR + REDES program provides free medicinal iron, like ferrous sulfate, at a national level. ${ }^{20}$ However, only $33 \%$ of infants aged 6-11 months and $9 \%$ of children aged 12-23 months receive it, and a higher use is observed among households without UBNs. ${ }^{10}$

Both the SAP and the AAP recommend a universal screening for $\mathrm{Hb}$ levels at 9 months old, ${ }^{1,3,18}$ but such requirement is not systematically met. ${ }^{19,22}$ There are regulations and consensuses in relation to anemia detection, screening, prevention, and management, as well as social assistance programs and a legal framework that establishes iron fortification of milk and flour; ${ }^{24}$ however, the prevalence of anemia is still high.

In 2000, a study done in Necochea about timely umbilical cord clamping showed the benefits for iron deficiency anemia (IDA) prevention, but the long-term follow-up was not completed..$^{25}$ No local studies have been done on the prevalence of IDA, ID, and risk factors or on the perspective of this condition among health care staff and families.

The purpose of this study was to clarify the local situation in the 6 to 12-month-old population. The objective of this study was to determine the prevalence of anemia and ID and its relation to dietary and medicinal iron intake, and the reason why iron supplementation is sometimes not administered.

\section{MATERIAL AND METHODS}

This was an observational, descriptive, and cross-sectional study. It included all healthy infants aged 6-12 months who attended a spontaneous health checkup in a public and/or private facility in the city of Necochea between February and December 2017. This was an attempt to prevent a selection bias. Children with an acute infectious disease were excluded. The sample size was estimated with the openEpi software, version 3.03, considering that $50 \%$ of average annual births (1496 neonates) ${ }^{29}$ would be between 6 and 11 months old for a disease with an hypothetical frequency of $45 \% \pm 5^{13}$ and an expected confidence interval (CI) of at least $95 \%$.

The pediatrician that assessed each infant requested the informed consent from their parent/legal guardian and administered the survey (Annex), performed the physical examination, and requested the lab tests. For anemia diagnosis, $\mathrm{Hb}$ levels were assessed considering anemia a level below $11 \mathrm{~g} / \mathrm{dL}$ (-2 SDs); ID was defined based on serum ferritin (SF) levels below $10 \mathrm{ng} / \mathrm{mL}$; the values published by the 2017 SAP guidelines were used as reference. Blood iron levels and transferrin saturation were ruled out given their high pre-analytical variability. All lab tests were done at the Department of Hematology of Hospital Dr. E. Ferreyra, in Necochea, using a Mindray $2300 \AA$ counter for $\mathrm{Hb}$ and a Metrolab 950 ELISA reader for SF.

Outcome measures were divided into 5 modules (Table 1). The first 2 modules included demographic outcome measures (age and sex) and perinatal outcome measures (birth weight, gestational age, and type of delivery) and described the characteristics of the study population. The other 3 modules allowed to establish indices for a better result interpretation.

The third module described the socioeconomic situation and established the educational environment index and the UBN index. The average number of years of completed education by the parents or the total years completed by the adult in charge of a single-parent household was obtained and classified into high (more than 13 years), middle (10-12 years), low (6-9 years), and very low (less than 6 years). ${ }^{13}$ The UBN index was established when at least one of the outcome measures required for adequate housing conditions was not met.

The outcome measures in the fourth module allowed to establish the iron intake index. These included the type of milk consumed and divided 
it based on iron bioavailability into adequate (breast milk or fortified milk) or scarce (nonfortified milk); meat intake the previous day and its association with facilitators or inhibitors of absorption; and medicinal iron intake and, if negative, the reason for it. Iron intake was defined as adequate if it included breastfeeding or fortified milk, food of animal origin, and medicinal iron administration. The absence of any of these 3 requirements was considered an inadequate intake.

The fifth module includes the lab tests used to assess iron metabolism ( $\mathrm{Hb}$ and $\mathrm{SF}$ ) and reflects the presence or absence of anemia and ID. The EpiInfo $^{\text {TM }}$ software, version 7.2, was used for statistical analysis. Measures of frequency and association were obtained, including relative risk (RR) with a $95 \% \mathrm{CI}$ and a $\chi^{2}$ test to establish an association for polytomous variables. The protocol was approved by the hospital's Board and Ethics Committee.

\section{RESULTS}

A total of 245 infants aged 6-12 months were included; 6 patients were excluded because they had an infectious disease at the time of the blood sample collection. The characteristics of the study population are presented in Table 2.

Anemia was observed in $50.6 \%$. The mean $\mathrm{Hb}$ level was $10.9 \mathrm{~g} / \mathrm{dL}(\mathrm{SD} \pm 0.94)$, with a total range of 7.1-14 g/ dL (range in the anemia population: 7.1-10.9 g/dL). Out of all children, $47.3 \%$ had ID, with a total ferritin range of 0.6-247 ng/ dL (range in the ID population: 0.6-9.7 $\mathrm{ng} / \mathrm{dL}$ ) and a mean of $12.7 \mathrm{ng} / \mathrm{dL}(\mathrm{SD} \pm 29.9)$.

Among all children with anemia, $54.4 \%$ had ID. In addition, among children without anemia, $43.3 \%$ had ID. Table 3 shows the comparative results of the different indices in relation to

TABLE 2. Characteristics of the study population (N: 239)

\begin{tabular}{|c|c|c|c|}
\hline & & Total & Percentage \\
\hline \multirow[t]{5}{*}{ Educational environment } & High & 94 & 39.3 \\
\hline & Middle & 79 & 33.0 \\
\hline & Low & 44 & 18.4 \\
\hline & Very low & 3 & 1.2 \\
\hline & ND & 19 & 7.9 \\
\hline \multirow[t]{3}{*}{ UBNs } & Yes & 47 & 19.6 \\
\hline & No & 174 & 72.8 \\
\hline & ND & 18 & 7.5 \\
\hline \multirow[t]{3}{*}{ Birth } & Preterm & 10 & 4.2 \\
\hline & Term & 211 & 88.3 \\
\hline & ND & 18 & 7.5 \\
\hline \multirow[t]{2}{*}{ Sex } & Female & 133 & 55.6 \\
\hline & Male & 109 & 44.4 \\
\hline \multirow[t]{6}{*}{ Age } & $6 \mathrm{mo}$ & 12 & 5.0 \\
\hline & $7 \mathrm{mo}$ & 82 & 34.3 \\
\hline & $8 \mathrm{mo}$ & 52 & 21.7 \\
\hline & $9 \mathrm{mo}$ & 32 & 13.4 \\
\hline & $10 \mathrm{mo}$ & 29 & 12.1 \\
\hline & $11 \mathrm{mo}$ & 32 & 13.4 \\
\hline \multirow[t]{3}{*}{ Delivery } & Vaginal & 103 & 43.0 \\
\hline & C-section & 116 & 48.5 \\
\hline & ND & 20 & 8.7 \\
\hline
\end{tabular}

UBNs: unmet basic needs; ND: no data.

TABLE 1. Outcome measure modules and indices obtained

\begin{tabular}{|c|c|c|c|c|}
\hline Demographic & Perinatal & Socioeconomic & Feeding & $\begin{array}{l}\text { Hematological } \\
\text { profile }\end{array}$ \\
\hline 口 & $\square$ & $\square$ & 口 & 口 \\
\hline$\square$ Age & $\square$ Type of delivery & $\square$ Maternal education & $\begin{array}{l}\square \text { Type of milk consumed } \\
\text { the previous day }\end{array}$ & $\square \mathrm{Hb}$ \\
\hline \multirow[t]{8}{*}{$\square \operatorname{sex}$} & $\square$ Birth weight & $\square$ Paternal education & $\begin{array}{l}\square \text { Meat intake the } \\
\text { previous day }\end{array}$ & $\square$ Ferritin \\
\hline & \multirow[t]{7}{*}{$\square$ Gestational age } & $\begin{array}{l}\square \text { INDEX: Educational } \\
\text { environment }\end{array}$ & $\square$ Facilitators & DINDEX:Anemia \\
\hline & & $\square$ Overcrowding & $\square$ Inhibitors & $\square$ INDEX: Iron \\
\hline & & $\square$ school attendance & $\square$ Medicinal iron & deficiency \\
\hline & & $\square$ Sewer system & $\square$ No iron intake & \\
\hline & & $\square$ Brick house & DINDEX: Iron intake & \\
\hline & & $\square$ Running water & & \\
\hline & & IINDEX: UBNs & & \\
\hline
\end{tabular}

$\mathrm{Hb}$ : hemoglobin; UBNs: unmet basic needs. 
anemia and ID, and their corresponding RR.

Regarding the characteristics of the study population, age showed a little association with the development of anemia ( $\left.\chi^{2}: 3.2[p: 0.6]\right)$, but a more clear one with ID ( $\chi^{2}: 9.7$ [p:0.08]). As age increased, the probability of ID was higher. Also, as age increased, iron intake decreased $\left(\chi^{2}: 12.2\right.$ [ $\left.\left.p: 0.03\right]\right)$. No differences were observed in the sex outcome measure in terms of anemia or ID prevalence (RR: 1.17 [95\% CI: 0.9-1.5]). Of all assessed infants, $4.5 \%$ had been born prematurely, and all of these had anemia and ID. An adequate birth weight was a protective factor against ID (RR: 0.16 [95\% CI: 0.02-0.9]), but not against anemia (RR: 0.4 [95\% CI: 0.1-1.3]). Finally, the type of delivery was not found to be a determinant of anemia (RR: 1.2 [95\% CI: 0.9-1.6]) or of ID (RR: 1 [95\% CI: 0.8-1.3]).

In relation to sociodemographic outcome measures, the presence of UBNs did not affect the development of anemia (RR: 1.2 [95\% CI: 0.8-1.8]) or of ID (RR: 1 [95\% CI: 0.7-1.3]). The household educational environment showed a strong association with the presence of anemia $\left(\chi^{2}: 7.9\right.$ [ $p: 0.04])$, but such association was not so clear with ID ( $\chi^{2}: 3$ [ $\left.\left.p: 0.4\right]\right)$, and demonstrated that a higher educational environment led to a lower probability of anemia.

An adequate iron intake did not affect the development of anemia (RR: 0.8 [95\% CI: 0.81.4]), but it was a protective factor against ID (RR: 0.7 [95 \% CI: 0.5-0.9]). Iron intake was inadequate in $61.7 \%$ of children. Of them, $70 \%$ had ID and $48.3 \%$, anemia. The breakdown of this index shows that $44.4 \%$ of surveyed participants did not receive medicinal iron. The reasons for this included forgetfulness (n: 33), no medical indication (n: 24), stomachache (n: 19), unavailability at the health care center (n: 9), considered unnecessary (n: 9), and other reasons (n: 4). Also, $81 \%$ of infants were breastfed and only $4.5 \%$ received non-fortified milk. Lastly,

TABLE 3. Comparative results of anemia and iron deficiency

\begin{tabular}{|c|c|c|c|c|c|c|c|c|}
\hline & & & \multicolumn{3}{|c|}{ Anemia } & \multicolumn{3}{|c|}{ Iron deficiency } \\
\hline & & $\mathbf{n}$ & $\begin{array}{l}\text { Yes } \\
\% \mathbf{n}\end{array}$ & $\begin{array}{l}\text { No } \\
\% \text { n }\end{array}$ & $\begin{array}{c}\text { RR } \\
(95 \% \mathrm{CI})\end{array}$ & $\begin{array}{l}\text { Yes } \\
\% \mathbf{n}\end{array}$ & $\begin{array}{l}\text { No } \\
\% \mathbf{n}\end{array}$ & $\begin{array}{c}\text { RR } \\
(95 \% \mathrm{CI})\end{array}$ \\
\hline Total & & 239 & 50.6 & & & 47.3 & & \\
\hline Sex & $\begin{array}{l}\text { Female } \\
\text { Male }\end{array}$ & $\begin{array}{l}130 \\
109\end{array}$ & $\begin{array}{c}46.1(60) \\
45(49)\end{array}$ & $\begin{array}{c}53.9(70) \\
55(60)\end{array}$ & $1.17(0.9-1.5)$ & $\begin{array}{l}45.5(59) \\
49.5(54)\end{array}$ & $\begin{array}{l}54.5(71) \\
50.5(55)\end{array}$ & $1.08(0.8-1.3)$ \\
\hline Delivery & $\begin{array}{l}\text { C-section } \\
\text { Vaginal } \\
\text { ND }\end{array}$ & $\begin{array}{c}116 \\
103 \\
20\end{array}$ & $\begin{array}{l}55.6(65) \\
43.3(44)\end{array}$ & $\begin{array}{l}44.4(51) \\
56.9(59)\end{array}$ & $1.29(0.9-1.7)$ & $\begin{array}{c}44(51) \\
47.5(49)\end{array}$ & $\begin{array}{c}56(65) \\
52.5(54)\end{array}$ & $1.06(0.8-1.4)$ \\
\hline Age & $\begin{array}{l}6 \text { months } \\
7 \text { months } \\
8 \text { months } \\
9 \text { months } \\
10 \text { months } \\
11 \text { months }\end{array}$ & $\begin{array}{l}12 \\
82 \\
52 \\
32 \\
29 \\
32\end{array}$ & $\begin{array}{c}50(6) \\
58.8(48) \\
48(25) \\
56.2(18) \\
51.7(15) \\
56.2(18)\end{array}$ & $\begin{array}{c}50(6) \\
41.2(34) \\
52(27) \\
43.8(14) \\
48.3(14) \\
43.8(14)\end{array}$ & & $\begin{array}{c}50(6) \\
36.2(30) \\
44.2(23) \\
47(15) \\
62(18) \\
62.5(20)\end{array}$ & $\begin{array}{c}50(6) \\
63.8(52) \\
55.8(29) \\
53(17) \\
38(11) \\
37.5(12)\end{array}$ & \\
\hline UBNs & $\begin{array}{l}\text { Yes } \\
\text { No } \\
\text { ND }\end{array}$ & $\begin{array}{c}47 \\
174 \\
18\end{array}$ & $\begin{array}{l}58.7(27) \\
49.1(86)\end{array}$ & $\begin{array}{l}41.3(20) \\
50.9(88)\end{array}$ & $1.23(0.8-1.7)$ & $\begin{array}{l}46.6(22) \\
54.6(95)\end{array}$ & $\begin{array}{l}53.3(25) \\
45.4(79)\end{array}$ & $1.02(0.7-1.4)$ \\
\hline $\begin{array}{l}\text { Educational } \\
\text { environment }\end{array}$ & $\begin{array}{l}\text { High } \\
\text { Middle } \\
\text { Low } \\
\text { Very low } \\
\text { ND }\end{array}$ & $\begin{array}{c}94 \\
79 \\
44 \\
3 \\
19\end{array}$ & $\begin{array}{c}43(40) \\
59.5(47) \\
50(22) \\
100(3)\end{array}$ & $\begin{array}{c}57(54) \\
40.5(32) \\
50(22) \\
0(0)\end{array}$ & & $\begin{array}{c}40.2(38) \\
51.9(41) \\
45.5(20) \\
67(2)\end{array}$ & $\begin{array}{c}59.8(56) \\
48.1(38) \\
54.5(24) \\
33(1)\end{array}$ & \\
\hline $\begin{array}{l}\text { Gestational } \\
\text { age }\end{array}$ & $\begin{array}{l}\text { Preterm } \\
\text { Term } \\
\text { ND }\end{array}$ & $\begin{array}{c}10 \\
211 \\
18\end{array}$ & $\begin{array}{c}100(10) \\
48.3(102)\end{array}$ & $\begin{array}{c}0(0) \\
51.7(109)\end{array}$ & & $\begin{array}{l}100(10) \\
43.3(91)\end{array}$ & $\begin{array}{c}0(0) \\
56.7(120)\end{array}$ & \\
\hline $\begin{array}{l}\text { Adequate } \\
\text { intake }\end{array}$ & $\begin{array}{l}\text { Yes } \\
\text { No } \\
\text { ND }\end{array}$ & $\begin{array}{c}85 \\
137 \\
17\end{array}$ & $\begin{array}{l}54.1(46) \\
48.2(66)\end{array}$ & $\begin{array}{l}45.9(39) \\
51.8(71)\end{array}$ & $1.1(0.8-1.4)$ & $\begin{array}{l}35.2(30) \\
51.8(71)\end{array}$ & $\begin{array}{l}64.8(55) \\
48.2(66)\end{array}$ & $0.75(0.6-0.9)$ \\
\hline
\end{tabular}

ND: no data; UBNs: unmet basic needs; RR: relative risk; CI: confidence interval. 
$42 \%$ had not consumed any type of food with a high iron bioavailability (meat) the previous day. In addition, $50.3 \%$ referred the intake of food that facilitated absorption, like citrus fruits, but only $15 \%$ did so in association with meat consumption.

\section{DISCUSSION}

Having full knowledge of all the effects caused by anemia on an individual's development, analyzing its status, and establishing that 1 in every 2 infants $(50.6 \%)$ aged 6-12 months has anemia should force us to seriously reconsider our duty as pediatricians. Some conditions are beyond our control. This is the case of the impact of the educational environment: anemia and ID were less common in households where caregivers had completed secondary school; however, it is clear that our professional background allows us to make many contributions based on an interdisciplinary work plan.

However, other outcomes observed in this study force us to have a self-critical approach. Namely, the small level of medicinal iron supplementation resulting from a lack of medical indication ( 1 in every 4 infants), insufficient supplies (1 in every 10 infants) or poor guidance (stomachache or forgetfulness in 1 in every 2 infants); this is similar to what has been described in other studies. ${ }^{15,19} \mathrm{~A}$ future challenge would be to analyze this topic specifically given the relevance of anemia and ID prevention. In this context, it is also valid to raise the need to assess other local strategies in relation to the type of supplementation selected in an attempt to improve iron intake.

As age increased, iron intake decreased; but at an older age, iron requirements were high and breastfeeding was not enough to meet them, as reflected by the higher prevalence of ID. The assessment of dietary iron intake showed that a high rate of children (2 in every 5 ) had not received food with a high iron bioavailability; of them, only 1 in every 6 infants consumed this food in association with facilitators of iron absorption. This study sought to approach the situation in this regard, but a deeper analysis is required, taking specific studies as reference. ${ }^{28}$

In relation to the type of milk consumed, more than $95 \%$ of infants received milk with a high iron bioavailability, and only 1 in every 20 infants received only non-fortified milk. This study was not aimed at assessing the breastfeeding index; however, results are not far from those obtained in the ENNyS or the National Breastfeeding Survey (Encuesta Nacional de Lactancia Materna, ENaLac). ${ }^{16}$ Exclusive breastfeeding did not have an effect on anemia and/or ID development. This is consistent with other studies. ${ }^{4}$ Most likely, this is due to iron fortification of infant formula, which has a smaller intestinal absorption but a higher iron concentration, which in the end achieves an adequate bioavailability.

As observed in other studies, ${ }^{4}$ the type of delivery did not have an effect on outcomes. In turn, a low birth weight was a risk factor for ID. All preterm infants had anemia and ID, but many of them received follow-up at the Department of Neonatology, so they could not be selected for inclusion in this study; this was probably a bias in the assessment of these two outcome measures. In addition, no differences were observed in the prevalence of anemia and/or ID based on sex or presence of UBNs.

Drake and Bernztein demonstrated a positive cost-benefit ratio in the prevention of ID, where for each dollar invested, 33.4 dollars were saved in economic losses resulting from anemia-associated conditions. ${ }^{22}$ With our support, government authorities should become aware of such knowledge and develop policies to that effect.

Although the SAP and the AAP recommend screening for anemia and ID before 12 months old, such practice is not generally reflected. This was introduced as an additional comment to the survey, so it should be analyzed in future studies.

For all these reasons, it is unavoidable to recognize the actual significance and importance of anemia in children and the society in general. In turn, it is necessary to have local information that can be compared to better adapt regulations and guide community efforts. Only this way it will be possible to strengthen known strategies and develop new ones to eradicate such unfair disease. This study describes several problems that should be further investigated.

\section{CONCLUSION}

The prevalence of anemia and iron deficiency in infants aged 6-12 months in the city of Necochea is high and even exceeds the national mean prevalence. ID is the main cause. A high educational environment and exogenous iron intake were protective factors against ID. This study showed that a high rate of children did not receive an adequate dietary or medicinal iron intake and that more than half of participating families had a middle or low educational environment. 


\section{Acknowledgments}

We would like to thank all the members of the Department of Pediatrics and the Department of Hematology of Hospital Dr. E. Ferreyra, in Necochea. Also, we would like to thank Silvia Do Santos, M.D. and Pediatric Hematologist of Hospital Interzonal Especializado Materno Infantil (HIEMI) Dr. V. Tetamanti, in Mar del Plata. In addition, we thank María Cristina Rapetti, Pediatric Hematologist of Hospital del Niño de San Justo, in La Matanza.

\section{REFERENCES}

1. Comité Nacional de Hematología, Oncología y Medicina Transfusional, Comité Nacional de Nutrición. Deficiencia de hierro y anemia ferropénica. Guía para su prevención, diagnóstico y tratamiento. Arch Argent Pediatr. 2017; 115(Supl 4):s68-82.

2. Glader B. Anemia ferropénica. In: Kliegman R, Behrman RE, Jenson HB, Stanton BF. Nelson Tratado de Pediatría. 18va ed. Vol II. Barcelona: Elsevier; 2009.Págs.2014-17.

3. Donato H, Rapetti C, Crisp R, Buys MC. Anemias Carenciales. In: Donato H, Rapetti C, Buys MC, Rossi N, et al. Anemias en pediatría. Temas de hematología para el médico pediatra. Buenos Aires: FUNDASAP; 2005.Págs.39-85.

4. IanicelliJC, Varea A, Falivene M, Disalvo L, etal. Prevalencia de anemia en lactantes menores de 6 meses asistidos en un centro de atención primaria de la ciudad de La Plata. Arch Argent Pediatr. 2012; 110(2):120-5.

5. Olivares GM, Walter KT. Consecuencias de la deficiencia de hierro. Rev Chil Nutr. 2003; 30(3):226-33.

6. Moráis López A, Dalmau Serra J, Comité de Nutrición de la AEP. Importancia de la ferropenia en el niño pequeño: Repercusiones y prevención. An Pediatr (Barc). 2011; 74(6):415-25.

7. Carter C, Jacobson J, Burden M, Armony-Sivan R, et al. Iron Deficiency Anemia and Cognitive Function in Infancy. Pediatrics. 2010; 126(2):e427-34.

8. Lozoff B, Jimenez E, Hagen J, Mollen E, et al. Poorer Behavioral and Developmental Outcome More Than 10 Years After Treatment for Iron Deficiency in Infancy. Pediatrics. 2000; 105(4):e51.

9. Donato H, Rapetti C, Morán L, Cavo M. Comparación entre hierro polimaltosa y sulfato ferroso para el tratamiento de la anemia ferropénica: estudio prospectivo aleatorizado. Arch Argent Pediatr. 2007; 105(6):491-7.

10. Olivares GM. Suplementación con Hierro. Rev Chil Nutr. 2004; 31(3):272-5.

11. Dirección Nacional de Maternidad e Infancia. Situación de la lactancia materna en Argentina. Buenos Aires: Ministerio de Salud de la Nación; 2015. [Accessed on: October 20 ${ }^{\text {th }}$, 2018]. Available at: http://www.msal.gob.ar/images/ stories / ryc/graficos / 0000001135 cnt-lactancia-maternaargentina-2015.pdf.

12. Kogan L, Abeya Gilardón E, Biglieri A, Mangialavori G, et al. Anemia: La desnutrición oculta. Resultados de la Encuesta Nacional de Nutrición y Salud -ENNyS-2008. Buenos Aires: Ministerio de Salud; 2008. [Accessed on: October 20 ${ }^{\text {th }}$,2018]. Available at: https: / / www.sap.org.ar/ docs / profesionales / anemia-la-desnutricion-oculta.pdf.

13. Mangialavori G, Biglieri A, Abeya Gilardón E, Duran P, et al. La alimentación de los niños menores de 2 años. Resultados de la Encuesta Nacional de Nutrición y Salud - ENNyS 2010. Buenos Aires: Ministerio de Salud; 2010. [Accessed on:October $20^{\text {th }}, 2018$ ]. Available at: http: / / www. msal.gob.ar/images/stories/bes/graficos/0000000258cnta09-alimentacion-de-ninos-menores-de-2-anos.pdf.
14. Mangialavori G, Biglieri A, Abeya Gilardón E, Duran P, et al. Alimentos consumidos en Argentina. Resultados de la Encuesta Nacional de Nutrición y Salud - ENNyS 2004/5. Buenos Aires: Ministerio de Salud;2012. [Accessed on: October $\left.20^{\text {th }}, 2018\right]$. Available at: http:/ / www.msal. gob.ar/images / stories / bes / graficos / 0000000259 cnt-a10alimentos-consumidos-en-argentina.pdf.

15. Christensen L, Sguassero Y, Cuesta C. Anemia y adherencia a la suplementación oral con hierro en una muestra de niños usuarios de la red de salud pública de Rosario, Santa Fe. Arch Argent Pediatr. 2013; 111(4):288-94.

16. Dirección Nacional de Maternidad, Infancia y Adolescencia. La Encuesta Nacional de Lactancia Materna (ENaLac). Buenos Aires: Ministerio de Salud de la Nación. 2017. [Accessed on: October 20 ${ }^{\text {th }}, 2018$ ]. Available at: http:// www.msal.gob.ar/plan-reduccion-mortalidad/boletin/ lactancia/noti1.php.

17. Binaghi MJ, Greco CB, López LB, Ronayne de Ferrer PA, et al. Biodisponibilidad de hierro en la dieta infantil. Arch Argent Pediatr. 2008; 106(5):387-9.

18. Baker R, GreerFR.Diagnosis and Prevention of IronDeficiency and Iron-Deficiency Anemia in Infants and Young Children (0-3 Years of Age). Pediatrics. 2010; 126(5):1040-50.

19. Bernztein R, Drake I. Subprescripción de hierro y variabilidad en el primer nivel de atención público de la Argentina. Arch Argent Pediatr. 2008; 106(4):320-7.

20. Ministerio de Salud y Desarrollo Social de la Nación. Secretaría de Gobierno deSalud. Medicamentos esenciales. Programa REMEDIAR+REDES. 2018. [Accessed on: October $\left.6^{\text {th }}, 2018\right]$. Available at: http://www.salud.gob. ar/medicamentos / index.php/noticias / 799-el-programaentrega-hierro-y-acido-folico-para-la-anemia.

21. Drake I, Bernztein R. Costo-beneficio de un programa preventivo y terapéutico para reducir la deficiencia de hierro en Argentina. Rev Panam Salud Pública. 2009; 25(1):39-46.

22. Sammartino G. Representaciones culturales acerca de la anemia y la suplementación con hierro. Arch Argent Pediatr.2010; 108(5):401-8.

23. Zlotkin S. Clinical nutrition: 8 . The role of the Nutrition in the prevention of iron deficiency anemia in infants, children and adolescents. CMAJ. 2003; 168(1):59-63.

24. Ley nacional 25.630. Buenos Aires, Argentina; 22 de agosto de 2002. [Accessed on: September 25 ${ }^{\text {th }}, 2018$ ]. Available at: http: / / www.anmat.gov.ar/Legislacion/Alimentos / Ley_25630.pdf.

25. Molina D, Rens V, Espelet L, Aguada E, et al. Evolución neonatal en recién nacidos de término, según el tiempo de ligadura del cordón umbilical. Arch Argent Pediatr. 2003; 101(1):9-15.

26. Lema S, Longo E, Lopresti A. Guías alimentarias: manual de multiplicadores. Buenos Aires: Asociación Argentina de Dietistas y Nutricionistas Dietistas, 2003.

27. World Health Organization. Guideline: Daily iron supplementation in infants and children. Geneva: World Health Organization; 2016. [Accessed on: October $20^{\text {th }}$ 2016]. Available at: https://www.who.int/nutrition/ publications / micronutrients / guidelines / daily_iron_ supp_childrens/en/.

28. Sguassero Y, Guerrero MM, Romero M. La visión de médicos pediatras de atención primaria de la salud sobre la anemia infantil y el suplemento con hierro. Arch Argent Pediatr. 2018; 116(1):21-7.

29. Dirección de estadísticas e información en salud (DEIS). Natalidad, Mortalidad general, Infantil y materna por lugar de residencia. ARGENTINA - AÑO 2015. Buenos Aires: Ministerio de Salud de la Nación; 2016, B [154]. [Accessed on: October 20 $\left.{ }^{\text {th }}, 2016\right]$. Available at: http:// www.deis.msal.gov.ar/wp-content/ uploads / 2016/12/ BoletinNro154xlugardeResidencia.pdf. 


\section{ANNEX}

1) IDENTIFICATION:

SEX: F M AGE:___ months old.

(Write the initials of first and last names).

\section{2) PERINATAL HISTORY:}

Birth weight: g.

Gestational age: weeks. Type of delivery:

\section{3) FAMILY AND SOCIOECONOMIC HISTORY:}

Maternal education (in completed years):

Paternal education (in completed years):

No. of household members: No. of rooms:

School attendance (school-age household member who does NOT attend school): YES. _ NO. House: Bricks._ Metal sheets.

Cesspit.___ Water: Running. Well. Excreta disposal: Sewer system.

\section{4) FEEDING}

Current breastfeeding: YES. NO.

Breastfeeding up to months old (only if the child is not currently breastfed).

Regarding consumption the previous day (ask what the infant consumed yesterday):
I. Breast milk only
IV. Breast milk and cow's milk.
II. Cow's milk only
V. Breast milk and fortified milk.
III. Fortified milk only
VI. Cow's milk and fortified milk.

Did the child eat meat yesterday (cow, chicken, fish, blood sausage, liver)?

No. Yes.

Did the child eat meat last week? (Only if the previous answer was No).

No. Yes.

Did the child eat citrus fruits yesterday?

No.__ Yes.

Did the child have any infusion yesterday (tea, coffee, mate, mate infusion, chocolate milk)?

No.__ Yes.

Did the child combine meat and infusions yesterday? (Ask only if the child ate meat the previous day).

No.__ Yes.

Did the child combine meat and citrus fruits yesterday? (Ask only if the child ate meat the previous day).

No. Yes.

Did the child receive iron yesterday?

No. Yes.

If Yes: How long has the child been taking iron?_months.

How many drops do you administer? drops.

If the child did not receive iron:

I. The doctor did not indicate it.

II. You did not consider it necessary.

III. It was not available at the hospital, primary health care center or pharmacy.

IV. It gave the child a stomachache.

V. You usually forget it.

VI. Other reason.

5) WEIGHT: kg. W/A: pctl W/H: pctl Height: cm. H/A: pctl

\section{6) LAB TESTS}

$\mathrm{Hb}$ : $\mathrm{mg} / \mathrm{dL}$

Blood iron: $\mu \mathrm{g} / \mathrm{dL}$.

Hct: $\quad \%$. Serum ferritin: $\mathrm{ng} / \mathrm{mL}$.

Transferrin sat.: $\%$ 